\title{
Unidade e Alteridade na Mensagem de Gálatas 3,26-28
}

Orientador: Prof. Isidoro Mazzarolo

Mestrando: Ailton Leite Rocha

Área de Concentração: Teologia Bíblica

Linha de Pesquisa: Análise e Interpretação de Textos do Antigo e Novo Testamento

O presente trabalho faz uma investigação exegética, buscando o resgate da mensagem de Gálatas 3,26-28. Compreende-se que a mensagem da perícope possui um chamamento para que as igrejas da Galácia busquem a unidade, mesmo diante da diversidade daquelas comunidades. A mensagem irradia de forma intensa a necessidade de igualdade nas relações entre os irmãos, relativizando as relações étnico-religiosas (judeu e grego), relações sociais (escravo e livre) e questões de gênero (homem e mulher). Para defender uma nova proposta de comunidade, um novo pacto, uma nova visão do sagrado e uma nova visão do outro, Paulo exorta os gálatas a não voltarem ao requisito e regime da Lei para serem filhos e povo de Deus, ele apresenta a fé como elemento necessário para a adoção. As assimetrias valorativas presentes nas igrejas da Galácia traziam problemas e impedimentos para a desejada e proclamada unidade. Ao propor uma simetria nas relações e relativizar os supostos valores étnico-religiosos, sociais ou de gênero, Paulo oferece a todos os gentios e pagãos uma leitura que permite a aproximação destes, sem que precise haver receio ou medo. Trata-se de uma abertura fabulosa na direção evangelizadora do mundo: a proposta ganha um aspecto universal, transcultural e arrefecedor das diferenças. O centro da mensagem é Jesus Cristo, para chegar até ele basta ter fé e assim ser co-participante da pertença do reino. Gálatas 3,26-28 é visto como o centro da epístola aos gálatas; a perícope é defendida como a síntese da mensagem que se queria proporcionalizar. 